\title{
Forty years of change in a monomictic tropical lake
}

Jemma M. Fadum ${ }^{1,2}$

jfadum@rams.colostate.edu

ORCID ID: 0000-0002-3206-4338

Ed K. Hall ${ }^{1,2,3}$

ed.hall@colostate.edu

ORCID ID: 0000-0001-8004-246X

${ }^{1}$ Graduate Degree Program in Ecology, ${ }^{2}$ Department of Ecosystem Science and Sustainability,

${ }^{3}$ Natural Resource Ecology Laboratory, Colorado State University, Fort Collins, CO, USA.

Running head: Forty years of change in a tropical lake

Keywords: tropical, lake, nitrogen, nutrient cycling, stratification, hypolimnion, global change, trophic state 


\begin{abstract}
Lakes across the world are experiencing increased trophic states, declining water quality and altered biogeochemical cycling due to the synergistic impacts of global change and local anthropogenic stressors. In the tropics, understanding the drivers of these changes can be difficult due to a lack of documented legacy conditions or continuous monitoring that can distinguish between intra- and inter-annual variation. Over the last forty years (1980-2020), Lake Yojoa, located in Honduras, has shifted from an oligotrophic to mesotrophic ecosystem as evidenced by a loss of water clarity. To assess the changes that have occurred in Lake Yojoa as well as putative drivers for those changes, we compared Secchi depth, dissolved inorganic nitrogen (DIN), and total phosphorus (TP) concentrations at bimonthly intervals for the three years between 1979-1983 and again at 16-day intervals for the two most recent years (20182020). While we found little change in TP between legacy and contemporary data, we found concurrent changes to seasonal trends in Secchi depth and DIN. Seasonal peaks in DIN coincident with mixing suggest that accumulation of ammonium in the hypolimnion during stratification, and release to the epilimnion with mixing maintains algal abundance in what was previously a nutrient-limited, clear water phase, driving a change in the overall trophic state. This interaction of seasonal dynamics with trophic state illustrates a key phenomenon in how physical structure and nutrients interact in monomictic tropical lakes and highlights the importance of warm anoxic hypolimnions to the biogeochemistry that governs the trophic state of these societally important ecosystems.
\end{abstract}




\section{Introduction}

It is increasingly evident that human activities (both local and global) are altering lake ecosystems around the world. The warming of surface water due to climate change is altering the duration of stratification and water column stability (Pilla et al. 2020) as well as intensifying eutrophication (Moss et al. 2011). In some regions, increased nitrogen supply has shifted the macronutrient that limits primary productivity from nitrogen $(\mathrm{N})$ to phosphorus $(\mathrm{P})($ Elser et al. 2009) and altered dissolved N:P stoichiometry of lakes (Isles et al. 2017). These impacts are often exacerbated by more localized aspects of global change including changes in land use that can result in enhanced loading of nutrients (Carpenter et al. 1998), metals (Yu et al. 2014), and organic pollutants (Lorgeoux et al. 2016) from the surrounding watershed.

Understanding which of these changes are affecting lakes in the tropics presents a challenge because of the paucity of monitoring efforts in many tropical regions (Bennun 2001; RiverosIregui et al. 2018). Without long-term datasets, it is difficult to distinguish between intra-annual variability, periodic or semi-periodic inter-annual variability (e.g., changes associated with El Niño-Southern Oscillation), and directional inter-annual changes. While studies of the African Great Lakes (Talling and Lemoalle 1998; Hecky 2000; Bootsma and Hecky 2003), Central American lakes such as Lake Atitlán (Corman et al. 2015; Weisman et al. 2018) and many Brazilian reservoirs and floodplain lakes (Tundisi et al. 1993; Melack et al. 2020) among many others, have made considerable contributions to tropical limnology, time series data remain far less common in tropical compared to temperate systems. This is, in part, due to the differences in abundance of lakes at temperate compared to tropical latitudes (Verpoorter et al. 2014) and also the legacy of a temperate lake focus in the field of limnology (Kilham and Kilham 1990). 
However, this discrepancy is improving as tropical limnology continues to advance (Ramírez et al. 2020).

Despite the critical role temperate lake studies play in the understanding of aquatic ecosystem nutrient dynamics, we cannot directly translate knowledge derived from the long-term monitoring of temperate lakes to tropical lakes because of inherent differences in basin morphology, hydrological drivers, climate, and seasonality that occur across latitudinal gradients. For example, temperature is unlikely to directly limit biogeochemical rate processes in tropical lake ecosystems (Talling and Lemoalle 1998), with perhaps the exception of some high elevation tropical lakes. Instead, redox conditions, or light availability are most likely to act as dominant controls over biogeochemical processes (Kilham and Kilham 1990).

However, temperature does have an important influence on the stratification regime and water column stability in the tropics (MacIntyre and Melack 2009). For lake basins that are deep enough to maintain stable stratification, annual water column temperature differences in tropical and subtropical regions regularly result in monomictic mixing regimes. These lakes and reservoirs normally mix once per year, most commonly during their hemispheric winter (Talling and Lemoalle 1998) or in association with other seasonal weather patterns (MacIntyre 2012). The time between the onset of stratification and mixing can lead to prolonged periods of anoxia in the hypolimnion. This anoxic period is biogeochemically active due to the warm temperature $\left(>20^{\circ} \mathrm{C}\right)$ of the hypolimnion in tropical lakes (Lewis 2002). The combination of warm temperatures and anoxic conditions selects for anaerobic metabolic pathways that are more likely to be thermodynamically constrained in the hypolimnions of temperate lakes.

To assess changes in trophic state and potential drivers of those changes in a large monomictic tropical lake, we compared two intensive sampling campaigns in Lake Yojoa 
(Honduras C.A.) that took place forty years apart. The first campaign sampled Lake Yojoa at three locations fortnightly from 1979 to 1983 (henceforth referred to as legacy sampling, Vaux and Goldman 1984). To create a comparative contemporary dataset, we sampled the lake at five pelagic stations (including three sites aligned with the three legacy locations) every 16 days from 2018 to 2020 . We then compared our contemporary results to those from the legacy period. The principal objectives of this study were to 1) identify changes in Lake Yojoa's trophic state over the past forty years, 2) identify differences in inter and intra-annual patterns in trophic state and 3) evaluate the potential drivers of observed changes in trophic state.

\section{Methods}

Study site

Lake Yojoa, located in west central Honduras (Figure 1; Table 1), is the largest freshwater lake in the country and the economic backbone of the surrounding region, supporting local livelihoods (e.g. fishing, agriculture, recreation, tourism) (Studer 2007). The watershed houses nine municipalities with an estimated combined population of over 74,000 (Rivera 2003).

\section{Sample collection}

All legacy data are
from the El Cajon Project
(Vaux and Goldman
1984). From September of
1979 to February of 1983 ,
samples were collected
bimonthly at three pelagic
stations. The most

All legacy data are from the El Cajon Project (Vaux and Goldman 1984). From September of stations. The most
Figure 1. Contemporary sampling stations within Lake Yojoa for biannual (A-R) and bimonthly (B, E, F, R and P) sampling. Principal tributaries 1) Rio Helado 2) Rio Balas 3) Rio Raices 4) Rio Varsovia 5) Rio Cacao 6) Rio Yure and outflow 7) Canal 
consistently sampled location ("Index") aligns with contemporary station E, while "Station 2 " aligns with contemporary station $\mathrm{F}$, and "Station 1 " is between stations R and P (Figure 1). Briefly, samples were analyzed for total phosphorus (TP), ammonium $\left(\mathrm{NH}_{4}^{+}\right)$, and nitrate $\left(\mathrm{NO}_{3}{ }^{-}\right)$as
Table 1. Physical characteristics of Lake Yojoa 1) Vaux and Goldman (1984) 2) Romero and Pineda (2007).

\begin{tabular}{|l|l|}
\hline Lake Area $\left(\mathrm{km}^{2}\right)$ & $\mathbf{8 8}^{1}$ \\
\hline Lake Volume $\left(\mathrm{km}^{3}\right)$ & $\mathbf{1 . 4}^{2}$ \\
\hline Elevation $(\mathrm{m}$ above sea level) & $\mathbf{6 3 8}^{1}$ \\
\hline Catchment Area $\left(\mathrm{km}^{2}\right)$ & $\mathbf{3 3 7}^{1}$ \\
\hline Mean Depth $(\mathrm{m})$ & $\mathbf{1 0}^{1}$ \\
\hline Maximum Depth $(\mathrm{m})$ & $\mathbf{2 7 . 3}^{2}$ \\
\hline
\end{tabular}

described below. Additionally, on each sampling campaign temperature and dissolved oxygen (DO) profiles of the water column were collected and Secchi depth was also measured (Vaux and Goldman 1984). Full details of sampling and analyses methods are available in Vaux and Goldman (1984).

For the contemporary sampling campaign, in collaboration with the Asociación de Municipios del Lago de Yojoa y su Área de Influencia, AMUPROLAGO, we collected water samples and took Secchi depth measurements and DO and temperature profiles every 16 days from March 2018 to January 2020. In addition to the bi-monthly epilimnetic sampling at five stations, in June of 2018 and 2019 and January of 2019 and 2020 we collected epilimnetic and hypolimnetic samples at each of the five regular stations (B, F, E, P and R) and 13 additional stations (18 sites in total, Figure 1). For all sampling efforts, temperature and DO profiles were measured at twometer intervals using a Hydrolab MS5 Multiparameter Sonde (OTT HydroMet, Loveland, CO). Epilimnetic samples were collected at one meter below the surface with an opaque Van Dorn water sampler and temporarily stored in opaque HDPE Nalgene bottles and placed in a cooler. Hypolimnetic samples were collected at all locations deep enough to be stratified during June sampling events. Samples were collected at a depth of two meters above the sediment (depths between 17-23 m) to ensure sampling occurred below the thermocline but above the sediment to 
avoid contamination. Whole water samples were frozen for TP analysis while $\mathrm{NH}_{4}{ }^{+}$and $\mathrm{NO}_{3}{ }^{-}$ samples were first filtered through $25 \mathrm{~mm}$ glass microfiber filters, Grade GF/F via Polysulfone filter funnels and then frozen. All samples were stored in $15 \mathrm{ml}$ centrifuge tubes before being transported to Fort Collins, CO, USA while frozen. Analyses were performed at the EcoCore facility at Colorado State University, Fort Collins, CO, USA as described below. Contemporary precipitation data was collected for this study at the AMUPROLAGO office (Figure 1) via HOBO U30 USB Weather Station Data Logger (Part \# U30-NRC).

\section{Nutrient enrichment bioassays}

In January and June of 2019, forty-eight clear glass bottles (120-mL) were filled with lake water from station $\mathrm{E}$ after passing the water through an $80 \mu \mathrm{m}$ mesh to remove grazers. In addition to the unamended control group, three treatment groups were prepared with twelve replicates each: +N (as $\mathrm{NH}_{4} \mathrm{SO}_{4}$, Sigma-Aldrich cat. no. A4418-100G), +P (as $\mathrm{K}_{2} \mathrm{PO}_{4}$, SigmaAldrich, cat. no. P3786-100G) and +NP. Concentration of nutrient amendments were chosen to approximately double in situ concentrations of $\mathrm{N}$ and $\mathrm{P}$ based on epilimnetic nutrient concentrations from March and June of 2018. N and P amendments in January 2019 were 6.92 $\mu \mathrm{M} N$ and $0.24 \mu \mathrm{M}$ P, final concentration. In June 2019, $\mathrm{N}$ and $\mathrm{P}$ amendments were $3.15 \mu \mathrm{M} \mathrm{N}$ and $0.94 \mu \mathrm{M}$ P, final concentration. We incubated each bottle in an outdoor water bath positioned near the lake as to expose bottles to ambient surface light conditions but buffer diel changes in air temperature. After three days, bottles were shaken thoroughly and algae from each bottle were collected on GF/F filters. Filters were folded, wrapped in tinfoil, and immediately frozen for transport to Fort Collins, CO. Within three days of sampling, chlorophyll $a(\operatorname{chl} a)$ was measured on a 10-AU fluorometer (Turner Designs Part No. 10-AU-074, calibrated using Turner Designs liquid chl $a$ standards) via extraction in $90 \%$ acetone with acidification to $0.003 \mathrm{~N} \mathrm{HCl}$ 
with $0.1 \mathrm{~N} \mathrm{HCl}$ (Arar 1997). Algal response for each treatment was recorded as percent increase from the mean algal concentration within the control treatment. We used pre-acidification values (chl $a$ plus phaeophytin) for all controls and treatments to represent total changes in algal biomass.

\section{Nutrient analyses}

During the legacy study, $\mathrm{NH}_{4}{ }^{+}$was measured using the indophenol method (Solórzano 1969), $\mathrm{NO}_{3}{ }^{-}$was measured using the hydrazine reduction method (Kamphake et al. 1967), and TP was first digested to soluble reactive phosphorus (SRP) via acid hydrolysis (using $\mathrm{H}_{2} \mathrm{SO}_{4}$ ) then measured using the ascorbic acid-molybdate method (Murphy and Riley 1962). For the contemporary sampling campaign, TP was first digested to SRP via the Alkaline Potassium Persulfate method under sub-boiling $\left(90^{\circ} \mathrm{C}\right)$ temperature, then measured using a colorimetric ascorbic acid assay (EPA Method 365.3 in U.S. Environmental Protection Agency 1983) modified to be analyzed on a UV-STAR Microplatte, 96 well via Infinite M200 TECAN at 880 nm absorbance detection. $\mathrm{NH}_{4}{ }^{+}$and $\mathrm{NO}_{3}{ }^{-}$were measured using a Flow Solution FS 3700 Automated Chemistry Analyzer (O.I. Analytical, College Station, TX). $\mathrm{NH}_{4}{ }^{+}$was determined by) an indophenol method (German Standard Methods, DIN in Society of German Chemists 1982). $\mathrm{NO}_{3}{ }^{-}$was determined via automated colorimetry (EPA Method 353.2 in O'Dell 1993) which relies on determination via diazotizing with sulfanilamide and coupling with N-(1-naphthyl)ethylenediamine dihydrochloride. $\mathrm{NH}_{4}{ }^{+}$and $\mathrm{NO}_{3}{ }^{-}$values are presented separately as well as combined and reported as dissolved inorganic nitrogen (DIN).

\section{Calculations and statistical analyses}

Data analyses were performed in $\mathrm{R}$ (version 4.0.2) using packages tidyverse (Wickham et al. 2019), ggplot2 (Wickham 2016), multcompView (Graves et al. 2019) and agricolae (de 
Mendiburu 2020) and base R. One-way analysis of variance (ANOVA) provided statistically significant differences for intra-annual and inter-annual comparisons of Secchi depth, DIN and TP. Treatment groups in the nutrient enrichment bioassay were compared using Tukey's HSD (honestly significant difference) test.

We calculated TSI for the lake for each sampling campaign using Secchi depth according to Carlson (1977). We chose this method over similar metrics such as Toledo (1983), Salas and Martino (1991), Lamparelli (2004), or Cunha (2013) due to the reliability and consistency of Secchi depth compared to other parameters, absence of chl $a$ values from the legacy campaign and concerns over under-estimation of trophic state of some models (Klippel et al. 2020).

$$
\operatorname{TSI}(S D)=10\left[6-\frac{\ln (S D)}{\ln (2)}\right]
$$

In addition to the nutrient enrichment bioassays, we calculated the molar ratio of dissolved inorganic $\mathrm{N}$ to Total P (DIN:TP) in the epilimnion between the two sampling periods to use as a proxy for potential macronutrient limitation of primary productivity (Wetzel 2001; Bergström 2010). We used the ratio DIN:TP> 10 to suggest $P$ limitation, $10>$ DIN:TP $>5$ to suggest colimitation and DIN:TP $<5$ to suggest N limitation (Wetzel 2001).

\section{Results}

\section{Stratification}

To determine the mixing regime of Lake Yojoa, we analyzed DO profiles from sampling events across the two years of contemporary monitoring. We determined that Lake Yojoa behaves as a monomictic system, with stratification establishing by April and mixing occurring in November (Figure 2a). In comparing temperature profiles between the two sampling periods, we saw increased temperature in the contemporary relative to the legacy period across all depths (Figure 2b). 


\section{Trophic state}

We assessed changes in Lake Yojoa's trophic state between the two sampling periods (inter-annual) and between months within each sampling period (intra-annual) by comparing mean annual Secchi depths. Mean annual Secchi depth and TSI from the legacy period (mean Secchi depth $=7.3 \pm$ standard deviation $2.1 \mathrm{~m}$, and TSI = $31.1 \pm 2.7)$ was significantly different $(p<0.001, \mathrm{df}=107)$ than present day conditions (mean

Secchi depth $=3.2 \pm 1.0 \mathrm{~m}$, and TSI $=43.3 \pm 31.5$, Figure 3 ).

These inter-annual differences in

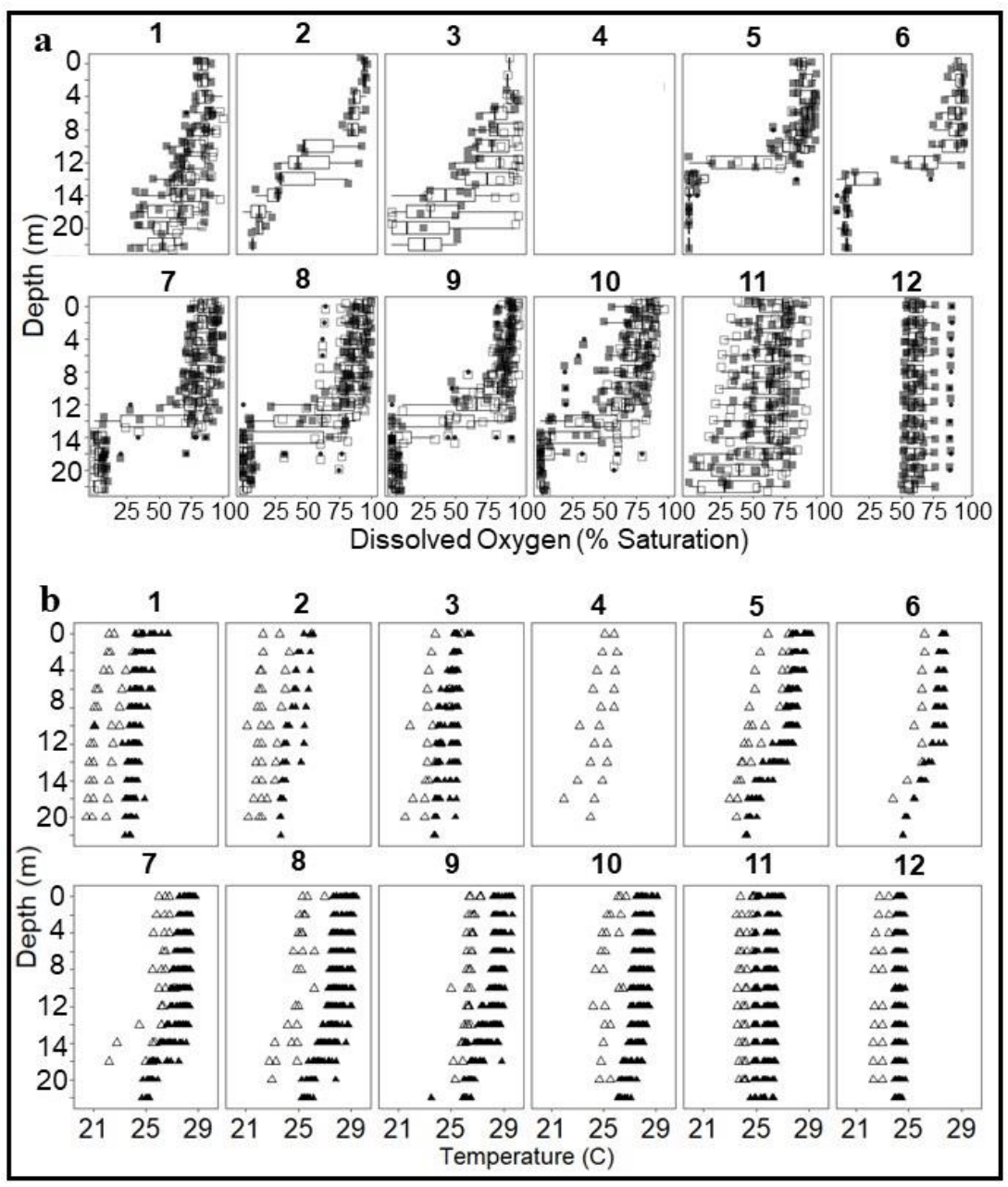

Figure 2. a) Dissolved oxygen profiles for contemporary sampling for all months (1-12) in 2019 (open squares) and 2020 (filled squares) over two-year boxplots (min, interquartile range, and max). b) Temperature profiles for each month of all years of contemporary (filled triangles) and legacy (open triangles) sampling. Due to sonde malfunction and the COVID-19 pandemic, profile data is unavailable for April of both 2019 and 2020.

trophic state were driven by intra-annual differences in trophic state between each sampling

period. In the early 1980s, Lake Yojoa experienced a clear water phase from August to March

(mean Secchi depth $=8.25 \pm 1.7 \mathrm{~m}$ and TSI $=29.8 \pm 2.7$ ) with annual minimum Secchi depth

(mean Secchi depth $=5.0 \pm 1.1 \mathrm{~m}$ and TSI $=37.0 \pm 3.4$ ) occurring between April and July

(Figure 4a). However, in the contemporary sampling, we observed no pronounced change in water clarity among seasons. Secchi depths for the months that previously had the minimum 
(April to July) had, on average,

$36 \%$ lower transparency (mean

Secchi depth $=3.2 \pm 1.0 \mathrm{~m}$ and TSI

$=44.2 \pm 4.8)$ in the contemporary

sampling. Similarly, the months

that previously had a clear water

phase (August - March) were

statistically indistinguishable

$(p=0.7, \mathrm{df}=87)$ from the months that

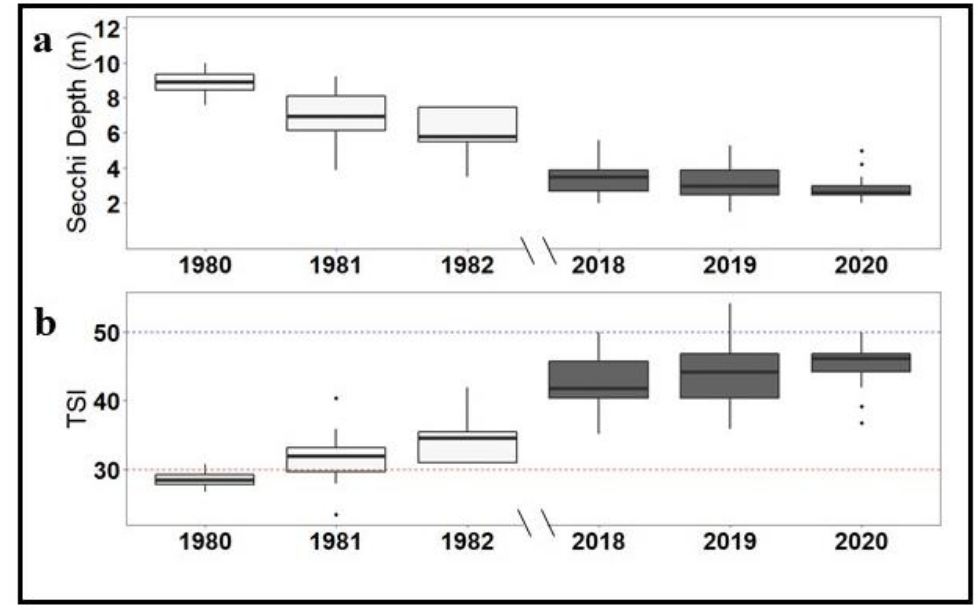

Figure 3. a) Secchi depths (m) and b) TSI at station $\mathrm{E}$ in all sampled years. The red dashed line marks the transition between oligotrophic and mesotrophic. The blue dashed line denotes the transition between mesotrophic and eutrophic.

had the annual minimum (mean Secchi depth $=3.2 \pm 1.0 \mathrm{~m}$ and TSI $=43.7 \pm 4.1$ ).

\section{Inorganic nitrogen and total phosphorus}

To evaluate putative drivers of

changes in trophic state of Lake

Yojoa we also assessed inter-

annual and intra-annual changes in

epilimnetic nutrient concentrations

between contemporary and legacy

periods. During the legacy period,

DIN varied throughout the year

but had no clear seasonality (mean

$\mathrm{DIN}=3.99 \pm 2.61 \mu \mathrm{M}$, Figure $4 \mathrm{~b}$ ).

During contemporary periods, mean annual DIN and intra-annual



b
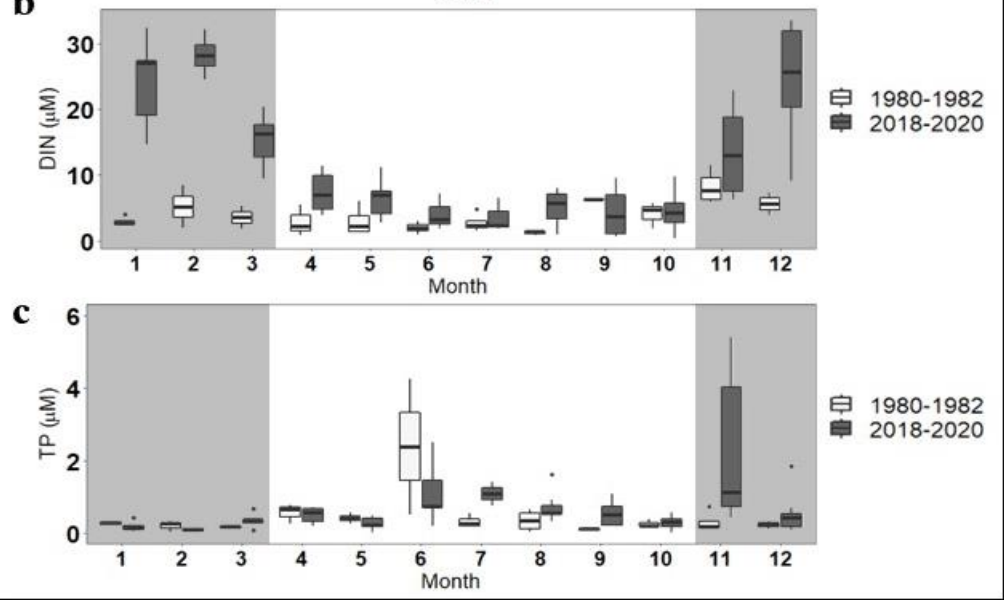

Figure 4. a) Secchi depths b) dissolved inorganic nitrogen (DIN) and c) total phosphorus (TP) at station E. Months with a mixed water column for the entire month or a portion of the month during 2018-2020 sampling shaded in grey. 
variation in DIN were greater than that observed during the legacy period (mean DIN $=12.28 \pm$ $9.85 \mu \mathrm{M}$, Figure $4 \mathrm{~b}$ ) with greater variance between contemporary and legacy periods (standard deviation DIN $=97.1$ vs. 6.80 , respectively). The increase in contemporary DIN was most pronounced directly following mixing in November (Figure 2a and 4b). After mixing, epilimnetic concentrations of DIN remained significantly higher $(p<0.001, \mathrm{df}=65)$ than premixing levels until the onset of stratification in April when epilimnetic DIN concentrations returned to pre-mixing levels (Figure 4b).

In contrast to DIN, contemporary TP values did not have increased seasonality in the contemporary period compared to the legacy period (Figure 4c). Mean annual TP values increased between legacy and contemporary periods $(0.41 \pm 0.67 \mu \mathrm{M}$ and $0.72 \pm 1.02 \mu \mathrm{M}$, respectively), but these differences were not significant $(p=0.1, \mathrm{df}=117)$. There was a pronounced increased in epilimnetic TP in June compared to other months of the year that was significant in the legacy ( $p<0.05$ for all months) but not significant different from the other months ( $p>0.5$ for all months) in the contemporary data. There was a second peak in the contemporary data in November, coincident with mixing. Contemporary epilimnetic TP $(2.20 \pm$ $1.93 \mu \mathrm{M})$ was somewhat higher relative the legacy period $(0.31 \pm 0.29 \mu \mathrm{M})$, but this difference also was not significant $(p=0.07, \mathrm{df}=14$, Figure $4 \mathrm{c})$.

We also compared differences in hypolimnetic concentrations of TP, $\mathrm{NH}_{4}{ }^{+}$and $\mathrm{NO}_{3}{ }^{-}$between legacy and contemporary periods for mixed (January) and stratified (June) sampling events to test if the increase in epilimnetic DIN and TP following November mixing was driven by changes in hypolimnetic $\mathrm{N}$ and $\mathrm{P}$ between sampling periods. During the legacy period, there was no significant difference between epilimnetic or hypolimnetic concentrations of $\mathrm{NO}_{3}^{-}(p=0.504$ 
Table 2. Epilimnetic and hypolimnetic nutrient concentrations for each sampling campaign at station E (mean \pm sd).

\begin{tabular}{|c|c|c|c|}
\hline \multicolumn{4}{|c|}{ January (Mixed) } \\
\hline & Total Phosphorus $(\mu \mathrm{M})$ & $\mathrm{NH}_{4}{ }^{+}-\mathrm{N}(\mu \mathrm{M})$ & $\mathrm{NO}_{3}^{-}-\mathrm{N}(\mu \mathrm{M})$ \\
\hline $\begin{array}{l}1980- \\
1982\end{array}$ & $\begin{array}{c}0.27 \pm 0.04 \text { (epi) } \\
0.42 \pm 0.11 \text { (hypo) }\end{array}$ & $\begin{array}{c}1.36 \pm 0.54 \text { (epi) } \\
3.86 \pm 2.49 \text { (hypo) }\end{array}$ & $\begin{array}{c}1.59 \pm 0.79(\text { epi) } \\
3.75 \pm 2.61 \text { (hypo) }\end{array}$ \\
\hline $\begin{array}{c}2018- \\
2020\end{array}$ & $\begin{array}{c}0.18 \pm 0.13(\text { epi) } \\
0.36 \pm 0.07(\text { hypo })\end{array}$ & $\begin{array}{c}7.65 \pm 7.88 \text { (epi) } \\
3.76 \pm 6.51 \text { (hypo) }\end{array}$ & $\begin{array}{l}16.54 \pm 11.72 \text { (epi) } \\
14.30 \pm 9.72 \text { (hypo) }\end{array}$ \\
\hline
\end{tabular}

\begin{tabular}{|c|c|c|c|}
\hline \multicolumn{4}{|c|}{ June and July (Stratified) } \\
\hline & Total Phosphorus $(\mu \mathrm{M})$ & $\mathbf{N H}_{4}{ }^{+}-\mathbf{N}(\boldsymbol{\mu M})$ & $\mathbf{N O}_{3}{ }^{-}-\mathbf{N}(\mu \mathbf{M})$ \\
\hline $\mathbf{1 9 8 0}$ & $1.01 \pm 1.60$ (epi) & $1.31 \pm 1.51$ (epi) & $1.19 \pm 0.53$ (epi) \\
$\mathbf{1 9 8 2}$ & $0.88 \pm 1.23$ (hypo) & $7.27 \pm 13.20$ (hypo) & $1.49 \pm 0.91$ (hypo) \\
\hline $\mathbf{2 0 1 8}$ & $1.12 \pm 0.75$ (epi) & $2.69 \pm 1.94$ (epi) & $1.17 \pm 0.75$ (epi) \\
$\mathbf{2 0 2 0}$ & $2.05 \pm 0.31$ (hypo) & $55.48 \pm 10.70$ (hypo) & $0.90 \pm 0.56$ (hypo) \\
\hline
\end{tabular}

$\mathrm{df}=9)$, TP $(p=0.884, \mathrm{df}=9)$, or $\mathrm{NH}_{4}{ }^{+}(p=0.298, \mathrm{df}=9)$ when the lake was stratified (Table 2). For the contemporary sampling period, during stratification, the hypolimnion of Lake Yojoa was significantly enriched in $\mathrm{NH}_{4}^{+}(p<0.001, \mathrm{df}=5)$ and marginally enriched in $\mathrm{TP}(p=0.078, \mathrm{df}=7)$ relative to the epilimnion (Table 2 ). We observed no significant $(p=0.67, \mathrm{df}=5)$ difference in $\mathrm{NO}_{3}{ }^{-}$between the two strata during the contemporary sampling period (Table 2). The initial increase in epilimnetic DIN following mixing was driven by an abrupt increase $\mathrm{NH}_{4}{ }^{+}$coincident with mixing, that was quickly converted to $\mathrm{NO}_{3}{ }^{-}$(Figure 5). $\mathrm{NO}_{3}{ }^{-}$remained the dominant DIN species in the epilimnion throughout the duration of the mixed water column phase (Figure 5).

\section{Nutrient limitation}

We evaluated nutrient limitation by comparing DIN:TP between each sampling period and conducting a nutrient limitation assay. In the legacy period, the ratio of DIN:TP (by atom)

fluctuated between

1.9 and 65.6; (Figure

6a). In contemporary

sampling we

observed a greater

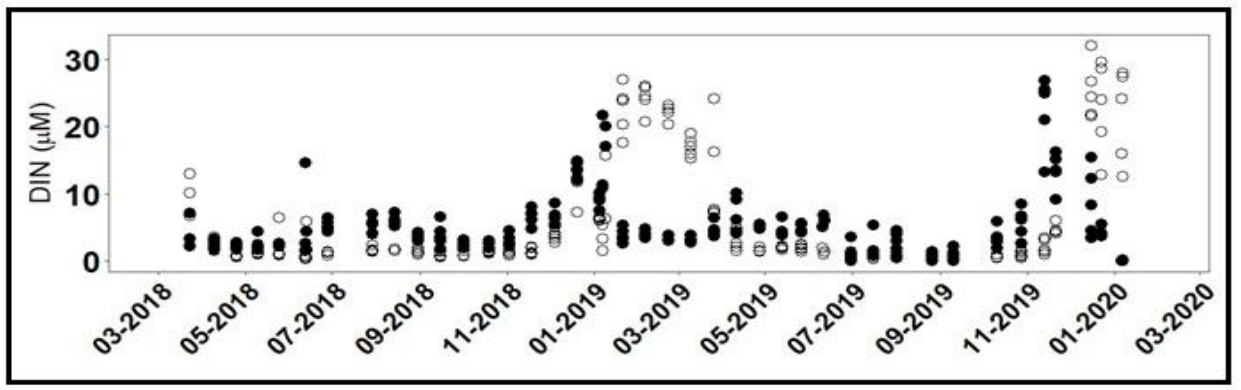

annual range of

Figure 5. Epilimnetic ammonium $\left(\mathrm{NH}_{4}{ }^{+}\right)$(filled circles) and nitrate $\left(\mathrm{NO}_{3}{ }^{-}\right)$(open circles) at stations $\mathrm{B}, \mathrm{E}, \mathrm{F}, \mathrm{P}$ and $\mathrm{R}$. 
DIN:TP (1.0 to 564.3) with a pronounced increase in DIN:TP directly following November mixing (Figure 6b).

We then directly tested the current state of macronutrient limitation in Lake Yojoa with two nutrient enrichment bioassays, one conducted in January when the water column was mixed and one conducted in June when the water column was stratified. In January, additions of $\mathrm{N}$ alone did not yield a significant increase in algal abundance relative to the control $(p=0.52$, $\mathrm{df}=32$ ). However, algal abundance was significantly greater in the $+\mathrm{P}$ and $+\mathrm{NP}$

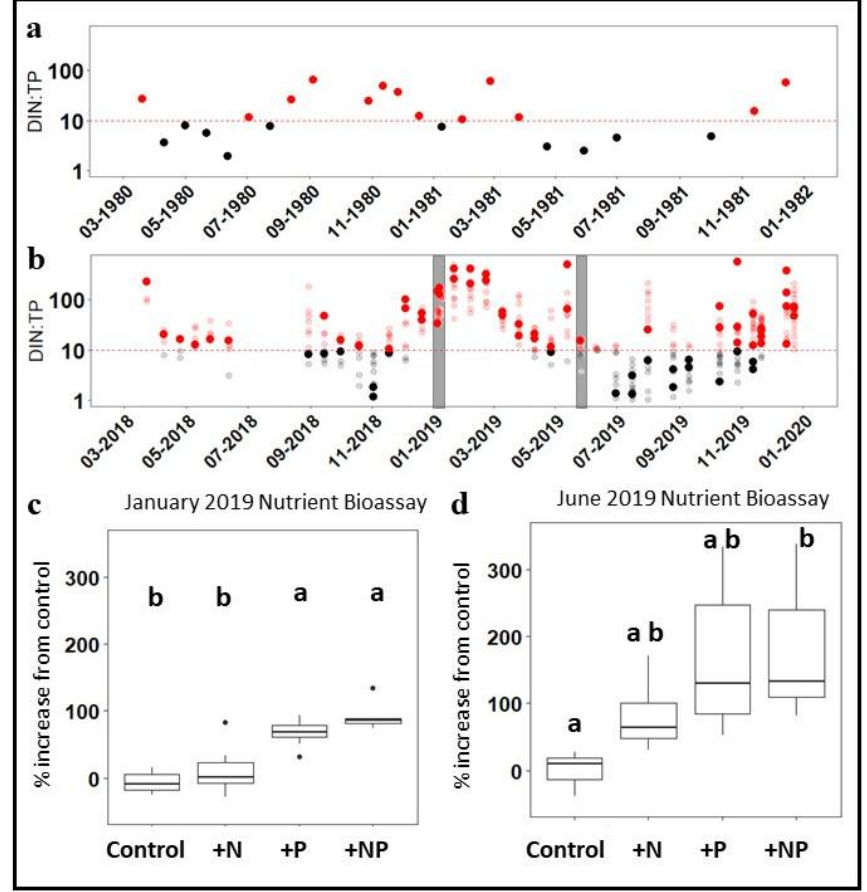

Figure 6. a) Legacy epilimnetic DIN:TP at location E b) contemporary DIN:TP at all locations (B, F, R, P and E bolded). Red indicates likelihood of $\mathrm{P}$ limitation above the red dashed line at DIN:TP $=10$. P limitation threshold suggested by Wetzel (2001). Grey bars indicate timing of nutrient enrichment bioassays c) Nutrient enrichment bioassay from location E conducted January 2019. d) Nutrient enrichment bioassay from location E conducted June 2019.

treatment groups than in both the control and $+\mathrm{N}$ treatments $(p<0.001, \mathrm{df}=32$, Figure $6 \mathrm{c})$, the $+\mathrm{P}$ and $+\mathrm{NP}$ groups were not significantly different from each other $(p=0.18, \mathrm{df}=32)$. In June, all treatments had a greater percent increase from the control than in January (Figure 6d). However, only treatments that received both $\mathrm{N}$ and $\mathrm{P}(+\mathrm{NP})$ were significantly different from the control group $(p=0.054, \mathrm{df}=17)$.

\section{Potential drivers}

To evaluate the sources of $\mathrm{N}$ to contemporary Lake Yojoa we assessed inter-annual delivery of allochthonous nutrients from the watershed using daily cumulative precipitation as a proxy for tributary discharge (and therefore watershed inputs). We compared daily cumulative 
precipitation in 2019 to epilimnetic

DIN and TP concentrations in the

pelagic zone of the lake $(\mathrm{B}, \mathrm{E}, \mathrm{F} \mathrm{P}$,

and $\mathrm{R}$ ) to assess the relationship

between peak rainfall events and

pelagic nutrient concentrations. We

found no corresponding increase in

epilimnetic nutrient concentrations

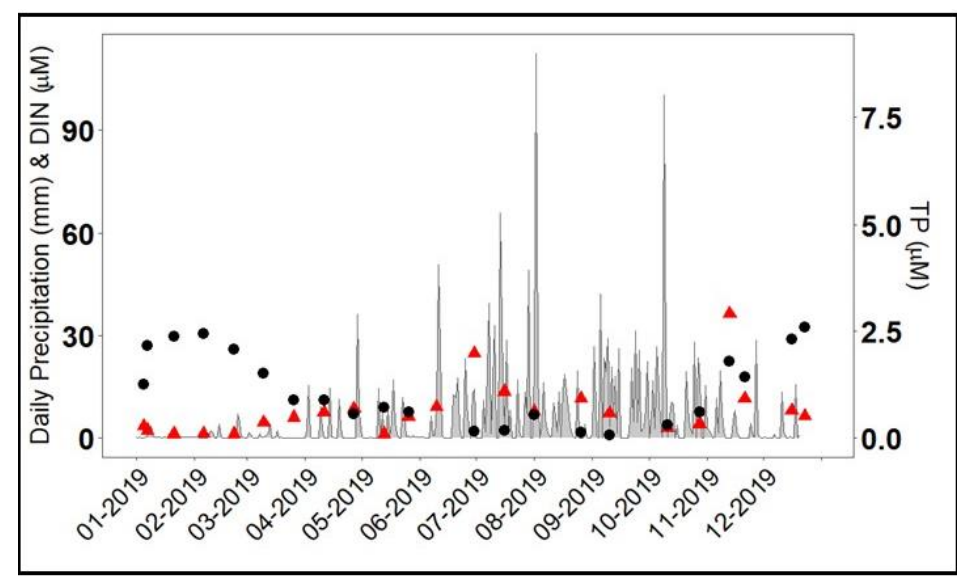

Figure 7. Daily precipitation (primary axis) and mean epilimnetic DIN (black circle) and TP (red triangles) at locations B, E, F, P and R (secondary axis).

concomitant with large precipitation events for any of the five principal sampling stations

(Figure 7).

We also assessed the spatial distribution of contemporary hypolimnetic nutrient values during stratified conditions for June 2018 and 2019 sampling campaigns. We hypothesized that if particulate nutrient load from tributaries was a major contributor to hypolimnetic nutrient accumulation, hypolimnetic nutrient concentrations would be greatest at sampling stations nearest tributaries (locations B, C, M, N, and O). However, mean hypolimnetic $\mathrm{NH}_{4}^{+}$

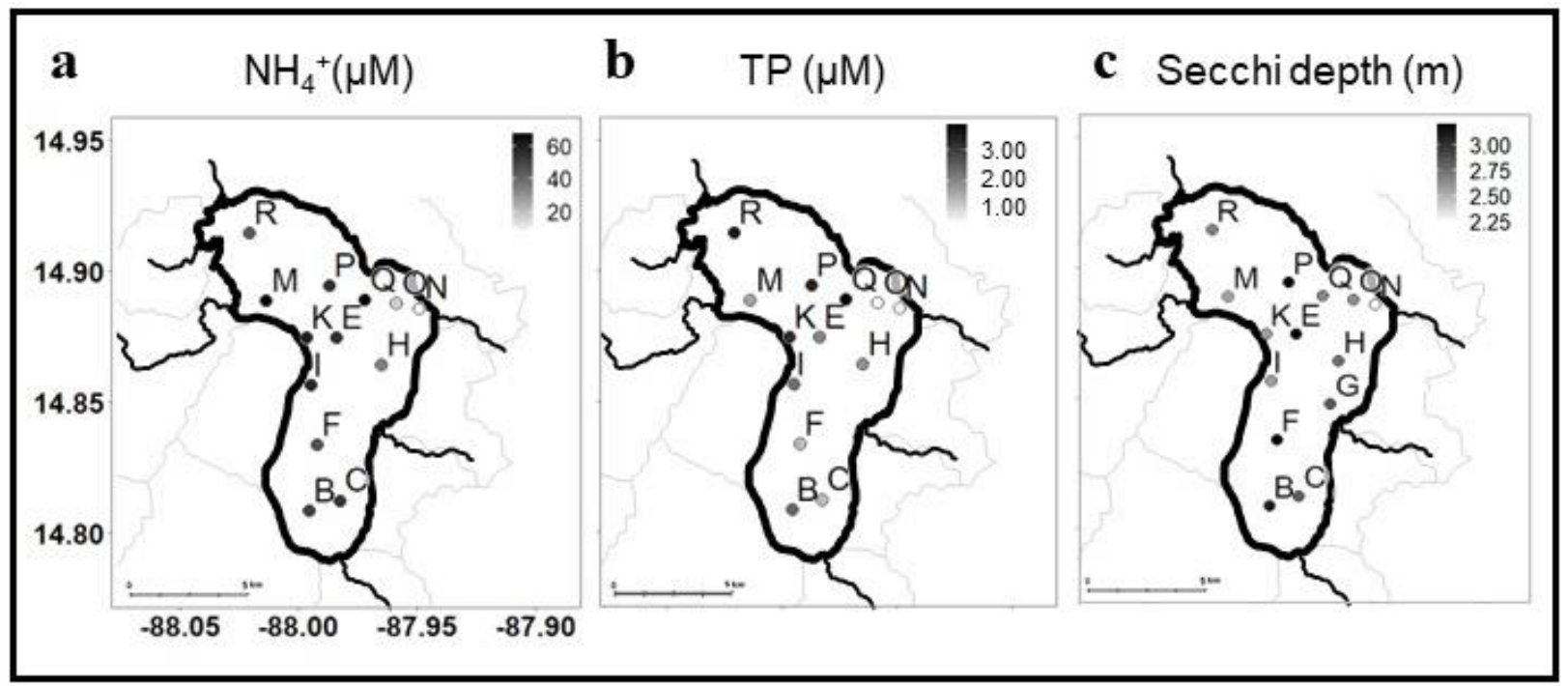

Figure 8. a) Mean hypolimnetic $\mathrm{NH}_{4}{ }^{+}$b) $\mathrm{TP}$ and c) Secchi depth in June (mean 2018 and 2019) during contemporary sampling. Values provided in Supplementary Table 1. 
concentrations at stations nearest the tributaries (locations $\mathrm{B}, \mathrm{C}, \mathrm{M}, \mathrm{N}$, and $\mathrm{O}$ mean $=39.03 \pm$ $26.02 \mu \mathrm{M})$ were nearly $17 \%$ less than the total hypolimnetic mean $(47.38 \pm 18.22 \mu \mathrm{M}$, Figure 8a). In contrast, hypolimnetic $\mathrm{NH}_{4}{ }^{+}$concentrations at stations in the deepest portion of the lake, $\mathrm{Q}, \mathrm{P}$, and $\mathrm{R}(55.79 \pm 11.42 \mu \mathrm{M})$ were, on average, approximately $17 \%$ greater than the total hypolimnetic mean. Hypolimnetic TP concentrations nearest the tributaries (mean $=1.39 \pm 0.74$ $\mu \mathrm{M})$ were approximately $37 \%$ less than the total hypolimnetic mean $(2.21 \pm 01.04 \mu \mathrm{M})$ and stations in the center of the lake (Q, P and R) had approximately $63 \%$ greater $\mathrm{TP}$ concentrations $(3.58 \pm 0.21 \mu \mathrm{M})$ than the total hypolimnetic mean (Figure $8 b)$. Secchi depth was statistically indistinguishable across regions $(p>0.5)$ with total lake mean $(2.79 \pm 0.30 \mathrm{~m})$, near-tributary mean $(2.68 \pm 0.32 \mathrm{~m})$, and mean of stations $\mathrm{Q}, \mathrm{P}$ and $\mathrm{R}(2.85 \pm 0.30 \mathrm{~m})$ all within the standard deviation of Secchi depth for the entire lake (Figure 8c).

\section{Discussion}

Comparison of legacy and contemporary periods showed that over the past forty years Lake Yojoa has transitioned from an oligotrophic system with a distinct clear water phase (August to March) to a mesotrophic system with low water clarity and the absence of any pronounced seasonal differences in water clarity. This change in trophic state was accompanied by accumulation of hypolimnetic $\mathrm{NH}_{4}{ }^{+}$during the stratified period and a release of nutrients to the epilimnion during mixing (usually in November). Delivery of $\mathrm{NH}_{4}{ }^{+}$from the hypolimnion to the photic zone during the dry season maintains Lake Yojoa's mesotrophic state and prevents the development of the clear water phase that was present during the legacy period. This transition from a stratified to mixed water column phase is also accompanied by a shift from $\mathrm{N}$ and $\mathrm{P}$ colimitation to $\mathrm{P}$ limitation (Figure 6). To explore drivers and consequences of these changes in the context of contemporary Lake Yojoa, as well as a broader understanding of similar monomictic 
tropical lakes in this discussion we focus on 1) potential sources of nutrients to Lake Yojoa, 2) implications for changing nutrient dynamics in other monomictic tropical lake systems, and 3) areas for further research.

\section{Sources of nutrients to Lake Yojoa}

Within the lake's watershed and the lake itself are several economic activities including approximately 55 lakeside restaurants, agricultural activities (e.g., cultivation of yuca, sugar cane, coffee, and pineapple), subsistence fishing, ranching, and industrial aquaculture (Studer 2007). Transport of reactive nutrients derived from activities within the watershed undoubtedly influence the biogeochemistry of Lake Yojoa. However, we did not see expected correlations between indicators of watershed loading and nutrient concentrations in the lake, as has been observed in other watersheds (Pandey and Verma 2004). Peak epilimnetic nutrient concentrations did not coincide with the rainy season when the majority of watershed discharge reaches the lake (Figure 7). There are, however, a few possible explanations for this observed asynchronicity. First, because the tributaries originate at higher elevations than the lake itself, the disconnect between epilimnetic nutrient concentrations and rain events could be explained by the subduction of cooler tributary waters and the formation of profile-bound density currents which could transport nutrients away from the littoral zone throughout the lake's hypolimnion, as has been observed in other systems (Talling and Lemoalle 1998). We hypothesized that increased hypolimnetic nutrient concentrations near the mouths of each tributary would suggest that loading from the watershed may be driving the accumulation of hypolimnetic nutrients. However, hypolimnetic sampling stations in the littoral zone near the mouths of tributaries were depleted in $\mathrm{NH}_{4}{ }^{+}$compared to sampling stations in the hypolimnion of the pelagic zone of the lake (Figure 8a). Second, the asynchronicity between watershed loading (as estimated by 
precipitation) and epilimnetic nutrient concentrations may be explained by nutrient assimilation driven by co-limitation, as suggested by the June nutrient bioassays, leaving reactive nutrients available for only a short period. High rates of nutrient allocation to biomass, not only in phytoplankton but also in aquatic macrophytes has been previously observed in tropical ecosystems (Esteves, 1982). However, Secchi depth was not significantly lower nearest the tributaries as would be expected if reactive nutrients were driving spatial differences in algal abundance or if watershed inputs during the rainy season were primarily in the form of suspended sediments and particulate $\mathrm{C}$ and $\mathrm{N}$, as observed in other tropical watersheds (McDowell and Asbury 1994). Therefore, we propose that the lack of spatial or temporal correlation between the watershed inputs and water column nutrient concentrations are consistent with the watershed not being the main driver of nutrient changes in Lake Yojoa.

Within the lake two small "artisanal" net-pen Tilapia farms are present, one in the northcentral region and one in the southern basin. There is also a large "industrial" net-pen Tilapia operation is in the north-central region of the lake (positioned nearest stations $\mathrm{P}, \mathrm{Q}$, and R, Figure 1). Net-pen aquaculture cannot treat effluent, and waste materials directly mix with the surrounding ecosystem. In other lakes, net-pen aquaculture has been shown to increase the trophic state and contribute to sediment nutrient concentrations (Troell and Berg 1997). Using data shared by the operator of the net-pen aquaculture (Regal Springs) for 2011 and 2013, we estimated annual nutrient loading from the aquaculture operation was between 353 to 395 metric tonnes of $\mathrm{N}$ and 44 to 55 metric tonnes of $\mathrm{P}$ year $^{-1}$ (pers. comm. Regal Springs). In addition to loading of dissolved nutrients, carbon (C) loading (particulate and dissolved) from the Tilapia farm may also be significant given the over 9000 tons of feed supplied to the Tilapia pens (based on 2011 and 2013 values), with loading estimates from previous studies on net-pen tilapia 
ranging from 81 to $91 \%$ of $\mathrm{C}$ in feed ultimately transferring to the surrounding environment (Gondwe et al. 2011). These estimates suggest the industrial aquaculture operation in Lake Yojoa represents a significant source of $\mathrm{N}$ and $\mathrm{P}$, to the lake and is a source that was not present during the legacy sampling campaign. The importance of the nutrients derived from net-pen aquaculture to the observations in the changing trophic state of Lake Yojoa are supported by our observations of enriched hypolimnetic $\mathrm{NH}_{4}{ }^{+}$and $\mathrm{TP}$ at stations nearest the aquaculture operation $(\mathrm{P}, \mathrm{Q}$ and $\mathrm{R}$ ) relative to the other stations in the lake, including those nearest the tributary mouths (Figure 8).

Another potential source of $\mathrm{N}$ loading to Lake Yojoa is atmospheric $\mathrm{N}$ deposition. While direct measurements of $\mathrm{N}$ deposition were unavailable for Lake Yojoa, estimates for the region range from 67.5 - $87.1 \mathrm{mg} \mathrm{N} \mathrm{m}^{-2}$ year $^{-1}$ (Dentener 2006). Given the surface area of Lake Yojoa $\left(88 \mathrm{~km}^{2}\right.$, Table 1), this would represent an annual deposition of between 5.9 and 7.6 metric tonnes per year which is approximately two orders of magnitude less than $\mathrm{N}$ loading from the aquaculture operation.

\section{Implications of ongoing change in Lake Yojoa}

Presently, Lake Yojoa is a monomictic lake that fully mixes annually in November (Figure 2a). This is consistent with patterns of mixing observed in 1979-1984 (Vaux and Goldman 1984). Therefore, the contemporary stratification conditions which allow for hypolimnetic nutrient accumulation existed in the 1980s, though in the 1980s both epilimnetic and hypolimnetic temperatures were slightly less than what is observed today (Figure 2b). In addition to the predicted seasonal mixing in November, during the contemporary sampling campaign, we also observed infrequent, ephemeral partial mixing events (i.e., only at some stations or not complete in depth with stratification quickly re-establishing) concurrent with large wind events 
and/or cold fronts (Figure 2a). Similar partial mixing events during the stratified season were also noted in the legacy data, as evidenced by anomalies in oxygen and temperature profiles, likely driven by large storm events (Vaux and Goldman 1984). However, these aseasonal mixing events have new ramifications under conditions of elevated levels of hypolimnetic nutrients in contemporary Lake Yojoa. Mixing events, during otherwise stratified months, introduce hypolimnetic nutrients to surface waters during peak annual temperatures. This pulse of nutrients can result in rapid increases in algal biomass (i.e., algal blooms). One such bloom occurred on June 9, 2020 and garnered national attention (La Tribuna 2020). If continued warming of the region (Aguilar et al. 2005) causes subsequent weaking of stratification stability, combined with increased intensity of weather events predicted with climate change (Knutson et al. 2010), these aseasonal mixing events may become more frequent, and result in increasing frequency of algal blooms during the stratified months.

The accumulation of hypolimnetic $\mathrm{NH}_{4}{ }^{+}$and subsequent release into the photic zone during the dry season when watershed inputs are low is a relatively recent development in Lake Yojoa. However, we hypothesize that a similar pattern of mixing and nutrient delivery during the dry season may be driving changes in trophic state in other monomictic tropical lakes. For example, winter mixing in Lake Titicaca (Peru-Bolivia) introduced large quantities of nutrients to the euphotic zone, temporarily alleviating $\mathrm{N}$ and $\mathrm{P}$ limitations (Vincent et al. 1984). In Valle de Bravo Reservoir (Mexico), N limitation during stratification was replaced by P limitation following mixing due to an increase in the DIN:TP ratio (Merino-Ibarra et al. 2008). These findings in other monomictic tropical systems are consistent with the results from the nutrient bioassays in this study where we found Lake Yojoa to be co-limited by $\mathrm{N}$ and $\mathrm{P}$ under stratified conditions but primarily $\mathrm{P}$ limited following mixing (Figure 6). Our nutrient limitation 
experiment results may have been influenced by the absence of atmospheric exchange and mixing, uncaptured growth on glass of the bottles (which we did not observe) and slightly greater temperature fluctuations than in situ conditions. However, these experimental artifacts would have equally impacted both the June and January experiments. Therefore, while algal abundance response to treatments may have been affected by some artifacts of our experimental design, the differences in response to each treatment should not be confounded with the date of the experiment.

\section{Areas for further research}

To better understand the drivers of hypolimnetic $\mathrm{NH}_{4}{ }^{+}$accumulation, we estimated changes in the rate of net hypolimnetic $\mathrm{NH}_{4}{ }^{+}$accumulation from January when the water column was mixed to July near peak stratification between contemporary and legacy periods. In the early 1980s, $\mathrm{NH}_{4}{ }^{+}$accumulated in the hypolimnion at an estimated rate of $0.04 \mu \mathrm{M}$ day $^{-1}$. Today, we estimate an accumulation rate of $0.33 \mu \mathrm{M}$ day $^{-1}$ over the same interval, a nearly tenfold increase in the rate of $\mathrm{NH}_{4}{ }^{+}$accumulation in the hypolimnion between the legacy and contemporary periods. This suggests that in addition to identifying potential sources of $\mathrm{N}$ to the hypolimnion, changes in $\mathrm{N}$ cycling pathways that both contribute (and remove) $\mathrm{NH}_{4}{ }^{+}$may be important aspects of the understanding how hypolimnetic processes contribute to Lake Yojoa's changing trophic state. There are five principal biogeochemical pathways that have the potential to influence the pool of $\mathrm{NH}_{4}{ }^{+}$in of Lake Yojoa: $\mathrm{N}$ fixation, nitrification, uptake, mineralization, and dissimilatory nitrate reduction to ammonium (DNRA). Of these, only uptake, mineralization, and DNRA, are likely to be active in the aphotic, anoxic hypolimnion.

Anaerobic processes occurring in the hypolimnion represent key pathways that result in the accumulation of hypolimnetic $\mathrm{NH}_{4}{ }^{+}$and appear to contribute most to the shifting trophic state of 
Lake Yojoa. Due to high loading of organic N estimated from the large-scale fish farm, mineralization, which can occur through a variety of respiratory pathways both aerobic and anaerobic, is likely the dominant mechanism for generation of $\mathrm{NH}_{4}{ }^{+}$in the hypolimnion. The large inputs of organic $\mathrm{N}$ from the fish farm (both urea and fecal pellets) as well as the warm temperatures present in the hypolimnion of Lake Yojoa likely result in accelerated rates of mineralization (Amado et al. 2013). In addition, if DNRA were to replace denitrification as a dominant pathway of nitrate reduction, DNRA could further enhance the accumulation of $\mathrm{NH}_{4}{ }^{+}$ in the hypolimnion. In other ecosystems, concentrated organic matter loading below aquaculture operations has been shown to increase DNRA rates up to seven-fold of ambient conditions (Christensen et al. 2000). This introduction of organic matter is particularly important because under conditions of low $\mathrm{NO}_{3}{ }^{-}$and high labile $\mathrm{C}$, DNRA is favored over complete denitrification (Nizzoli et al. 2010), the dominant loss pathway for reactive $\mathrm{N}$ in most lake ecosystems. Given the large inputs of $\mathrm{C}$ that are likely associated with the industrial Tilapia operation in the deepest basin of the lake, it is possible that conditions that favor DNRA are present in the hypolimnion of Lake Yojoa today. Conditions that result in the selection for DNRA over denitrification would further promote the accumulation of $\mathrm{NH}_{4}{ }^{+}$, whereas legacy conditions (e.g., lower organic $\mathrm{C}$ inputs) may have favored denitrification and the loss of reactive $\mathrm{N}$ from the lake, preventing the accumulation of hypolimnetic $\mathrm{NH}_{4}{ }^{+}$.

\section{Conclusion}

The results from this study along with similar observations in other monomictic tropical lakes (Vincent et al. 1984, Merino-Ibarra et al. 2008) suggests that an improved understanding of hypolimnetic nutrient accumulation and release is necessary to better understand how anthropogenic changes are influencing the trophic state of monomictic tropical lake ecosystems. 
In monomictic tropical lakes, the interaction of the physical structure of the water column and nutrient loading places hypolimnetic processes at the intersection of local drivers (such as nutrient loading) and global drivers (such as climate change, due to its potential to influence physical structure of the water column). Further research on tropical, monomictic lake ecosystems should aim to understand the controls on biogeochemical pathways that lead to the accumulation of hypolimnetic nutrients, how differences between epilimnetic and hypolimnetic nutrient concentrations influence nutrient limitation, and how seasonal changes to primary productivity are driven by the physical structure of the lake.

\section{Acknowledgements}

We would like to thank the entire staff of AMUPROLAGO for their efforts in this collaboration, in particular Juan Carlos Sorto for sample collection. Regal Springs Inc. provided $\mathrm{N}$ and $\mathrm{P}$ loading estimates from their aquaculture operation. We thank Charles Goldman and Peter Vaux for sharing the original, hand-written data from the legacy study. This project benefitted greatly from the support of Casey Barby both in the field and in the lab. This manuscript was greatly improved by valuable feedback from John Melack and André Amado. Funding was provided by the Warner College of Natural Resources and Department of Ecosystem Science and Sustainability at Colorado State University (CSU) with additional support from the Graduate Degree Program in Ecology and the Natural Resource Ecology Lab at CSU. Additional travel support was provided by two airfare vouchers from United Airlines. We have no conflicts of interest to declare.

\section{References}

Arar, E. J., and G. B. Collins. 1997. Method 445.0 In Vitro Determination of Chlorophyll a and Pheophytin a in Marine and Freshwater Algae by Fluorescence. U.S. Environmental 


\section{Protection Agency, Washington, DC}

Aguilar, E., T. C. Peterson, P. R. Obando, and others. 2005. Changes in precipitation and temperature extremes in Central America and northern South America, 1961-2003. J. Geophys. Res. Atmos. 110: 1-15. doi:10.1029/2005JD006119

Amado, A. M., F. Meirelles-Pereira, L. O. Vidal, H. Sarmento, A. L. Suhett, V. F. Farjalla, J. B. Cotner, and F. Roland. 2013. Tropical freshwater ecosystems have lower bacterial growth efficiency than temperate ones. Front. Microbiol. 4. doi:10.3389/fmicb.2013.00167

Bennun, L. A. 2001. Long-term monitoring and the conservation of tropical wetlands: High ideals and harsh realities. Hydrobiologia. 458: 9-19. doi: 10.1023/A:1013159406391

Bergström, A. K. 2010. The Use of TN:TP And DIN:TP ratios as indicators for phytoplankton nutrient limitation in oligotrophic lakes affected by N deposition. Aquat. Sci.72: 277-281. doi:10.1007/s00027-010-0132-0

Bootsma, H. A., and R. E. Hecky. 2003. A comparative introduction to the biology and limnology of the African great lakes. J. Great Lakes Res. 29: 3-18. doi:10.1016/S0380$1330(03) 70535-8$

Carlson, R. E. 1977. A trophic state index for lakes. Limnol. Oceanogr. 22: 361-369. doi:10.4319/lo.1977.22.2.0361

Carpenter, S. R., N. F. Caraco, D. L. Correll, R. W. Howarth, A. N. Sharpley, and V. H. Smith. 1998. Nonpoint pollution of surface waters with phosphorus and nitrogen. Ecol. Appl. 8: 559-568. doi:10.1890/1051-0761(1998)008[0559:NPOSWW]2.0.CO;2

Christensen, P., S. Rysgaard, N. Sloth, T. Dalsgaard, and S. Schwærter. 2000. Sediment mineralization, nutrient fluxes, denitrification and dissimilatory nitrate reduction to ammonium in an estuarine fjord with sea cage trout farms. Aquat. Microb. Ecol. 21: 73-84. 
doi:10.3354/ame021073

Corman, J. R., E. Carlson, M. Dix, and others. 2015. Nutrient dynamics and phytoplankton resource limitation in a deep tropical mountain lake. Inl. Waters 5: 371-386. doi:10.5268/IW-5.4.843

Cottingham, K. L., H. A. Ewing, M. L. Greer, C. C. Carey, and K. C. Weathers. 2015. Cyanobacteria as biological drivers of lake nitrogen and phosphorus cycling. Ecosphere 6: 1-19. doi:10.1890/ES14-00174.1

Cunha, D. G. F., M. do C. Calijuri, and M. C. Lamparelli. 2013. A trophic state index for tropical/subtropical reservoirs (TSItsr). Ecol. Eng. 60: 126-134. doi:10.1016/J.ECOLENG.2013.07.058

Dentener, F. J. 2006. Global maps of atmospheric nitrogen deposition, 1860, 1993, and 2050. ORNL DAAC, Oak Ridge, Tennessee, USA. https://doi.org/10.3334/ORNLDAAC/830. Elser, J. J., T. Andersen, J. S. Baron, and others. 2009. Shifts in lake N:P stoichiometry and nutrient limitation driven by atmospheric nitrogen deposition. Science. 326: 835-7. doi:10.1126/science.1176199

Esteves, F.A., 1982. Biomass and analysis of the major inorganic components of floating aquatic macrophyte (. Eichhornia crassipes) (mart). Solms) in six reservoirs of São Paulo State (Brasil). Ciencia e Cultura. 34: 1196-1200

Gondwe, M. J. S., S. J. Guildford, and R. E. Hecky. 2011. Carbon, nitrogen and phosphorus loadings from tilapia fish cages in Lake Malawi and factors influencing their magnitude. J. Great Lakes Res. 37: 93-101. doi:10.1016/j.jglr.2010.11.014

Graves, S., H. P. Piepho, and L. Selzer. 2019. multcompView: Visualizations of Paired Comparisons. https://CRAN.R-project.org/package=multcompView 
Hecky, R. E. 2000. Aquatic ecosystem health \& management A biogeochemical comparison of Lakes Superior and Malawi and the limnological consequences of an endless summer. Aquat. Ecosyst. Heal. Manag. 3: 23-33. doi:10.1080/14634980008656988

Isles, P. D. F., Y. Xu, J. D. Stockwell, and A. W. Schroth. 2017. Climate-driven changes in energy and mass inputs systematically alter nutrient concentration and stoichiometry in deep and shallow regions of Lake Champlain. Biogeochemistry 133: 201-217. doi:10.1007/s10533-017-0327-8

Kamphake, L. J., S. A. Hannah, and J. M. Cohen. 1967. Automated analysis for nitrate by hydrazine reduction. Water Res. 1: 205-216. doi:10.1016/0043-1354(67)90011-5

Kilham, S. S., and P. Kilham. 1990. Tropical limnology: Do African lakes violate the "first law" of limnology? SIL Proceedings, 1922-2010 24: 68-72. doi:10.1080/03680770.1989.11898692

Klippel, G., R. L. Macêdo, and C. W. C. Branco. 2020. Comparison of different trophic state indices applied to tropical reservoirs. Lakes Reserv. Res. Manag. 25: 214-229. doi:10.1111/lre.12320

Knutson, T. R., J. L. McBride, J. Chan, and others. 2010. Tropical cyclones and climate change. Nat. Geosci. 3: 157-163. doi:10.1038/ngeo779

La Tribuna. 2020. Investigarán contaminación del Lago de Yojoa por sustancia. La Tribuna, June 12

Lamparelli, M. C. 2004. Grau de trofia em corpos d'água do estado de São Paulo: avaliação dos métodos de monitoramento. Ph.D. thesis. Universidade de São Paulo.

Lewis, W. M. 2002. Causes for high frequency of nitrogen limitation in tropical lakes. Verh. Internat. Verein. Limnol 28: 210-213. 
Lorgeoux, C., R. Moilleron, J. Gasperi, S. Ayrault, P. Bonté, I. Lefèvre, and B. Tassin. 2016.

Temporal trends of persistent organic pollutants in dated sediment cores: Chemical

fingerprinting of the anthropogenic impacts in the Seine River basin, Paris. Sci. Total

Environ. 541: 1355-1363. doi:10.1016/j.scitotenv.2015.09.147

MacIntyre, S. 2012. Mixing dynamics in lakes across climatic zones., p. 311-336. In C.

Goldman, M. Kumagai, and R. Robarts [eds.], Climatic Change and Global Warming of

Inland Waters: Impacts and Mitigation for Ecosystems and Societies. John Wiley \& Sons,

Ltd.

MacIntyre, S., and J. Melack. 2009. Mixing dynamics in lakes across climatic zones, p. 603-612.

In Encyclopedia of Ecology of Inland Water. Elsevier.

McDowell, and C. Asbury. 1994. Export of carbon, nitrogen, and major ions from three tropical montane watersheds. Limnol. Oceanogr. 39: 111-125, doi: 10.4319/lo.1994.39.1.0111

Melack, J., D. Kasper, J. Amaral, P. Barbosa, and B. Forsberg. 2020. Limnological perspectives on conservation of floodplain lakes in the Amazon basin. Aquat. Conserv. Mar. Freshw. Ecosyst. 30. doi: 10.1002/aqc. 3556

de Mendiburu, F. 2020. Agricolae: Statistical Procedures for Agricultural Research. https://CRAN.R-project.org/package=agricolae

Merino-Ibarra, M., E. Monroy-Ríos, G. Vilaclara, F. S. Castillo, M. E. Gallegos, and J. RamírezZierold. 2008. Physical and chemical limnology of a wind-swept tropical highland reservoir. Aquat. Ecol. 42: 335-345. doi:10.1007/s10452-007-9111-5

Moss, B., S. Kosten, M. Meerhoff, and others. 2011. Allied attack: climate change and eutrophication. Inland Waters. 1:101-105. doi:10.5268/IW-1.2.359

Murphy, J., and J. R. Riley. 1962. A modified single solution method for the determination of 
phosphate in natural waters. Anal. Chim. Acta 27: 31-36. doi: 10.1016/S00032670(00)88444-5

Nizzoli, D., E. Carraro, V. Nigro, and P. Viaroli. 2010. Effect of organic enrichment and thermal regime on denitrification and dissimilatory nitrate reduction to ammonium (DNRA) in hypolimnetic sediments of two lowland lakes. Water Res. 44: 2715-2724.

doi:10.1016/j.watres.2010.02.002

O'Dell, J. 1993. Methods for the determination of inorganic substances in environmental samples. U.S. Environmental Protection Agency, Washington, D.C., EPA-600-R-93-100 (NTIS PB94121811).

Pandey, J. D., and A. Verma. 2004. The influence of catchment on chemical and biological characteristics of two freshwater tropical lakes of southern Rajasthan. J Environ Biol. 25: $81-87$.

Pilla, R. M., C. E. Williamson, B. V. Adamovich, and others. 2020. Deeper waters are changing less consistently than surface waters in a global analysis of 102 lakes. Sci. Rep. 10: 1-15. doi:10.1038/s41598-020-76873-X

Ramírez, A., M. Caballero, G. Vázquez, and C. Colón-Gaud. 2020. Preface: Recent advances in tropical lake research. Hydrobiologia 847: 4143-4144. doi:10.1007/s10750-020-04443-3

Rivera, C. 2003. Plan de manejo de la cuenca del Lago de Yojoa. Available at: scribd.com/doc/20184488/Plan-de-Manejo-Lago-Yojoa-Honduras. Last accessed February 1, 2021.

Riveros-Iregui, D., T. Covino, and R. González-Pinzón. 2018. The importance of and need for rapid hydrologic assessments in Latin America. Hydrological Processes. 32: 2441-2451. doi: 10.1002/hyp.13163 
Romero, F., and Pineda, N. 2007. Batimetría del Lago de Yojoa. Revista Técnico-Científica

Tatascan. 19. Available at: fao.org/fileadmin/user_upload/training_material/docs/

Batimetr\%C3\%Ada\%20de1\%20Lago\%20de\%20Yojoa.pdf. Last accessed February 1, 2021.

Salas, H., and P. Martino. 1991. A Simplified Phophorus Trophic State Model for Warm-Water

Tropical Lakes. Wat. Res. 25: 341-350. doi: 10.1016/0043-1354(91)90015-I

Society of German Chemists. 1982. Deutsche Einheitsverfahren zur Wasser-, Abwasser- und

Schlammuntersuchung: Kationen (Gruppe E). Weinheim, Germany, DIN 38406.

Solórzano, L. 1969. Determination of ammonia in natural waters by the phenolhypochlorite method. Limnol. Oceanogr. 14: 799-801, doi:10.4319/lo.1969.14.5.0799

Studer, E. 2007. La contaminación ambiental del Lago de Yojoa : Un estudio bibliográfico respecto a un sistema de indicadores ambientales. Masters Thesis. École Polytechnique Fédérale de Lausanne. Available at: repositorio.credia.hn/bitstream/handle /123456789/137/2007_contaminacion_ambiental_del_lago_de_yojoa.pdf?sequence=1\&isAl lowed=y. Last accessed February 1, 2021.

Talling, J., and J. Lemoalle. 1998. Ecological Dynamics of Tropical Inland Waters, Cambridge University Press.

Toledo, A. P., M. Talarico, S. Chinez, and E. Agudo. 1983. Aplicação de modelos simplificados para a avaliação de processo da eutrofização de lagos e reservatórios tropicais. Revista DAE. 68: 142-156.

Troell, M., and H. Berg. 1997. Cage fish farming in the tropical Lake Kariba, Zimbabwe: impact and biogeochemical changes in sediment. Aquac. Res. 28: 527-544. doi:10.1046/j.13652109.1997.00889.x

Tundisi, J. G., T. Matsumura-Tundisi, and M. C. Calijuri. 1993. Limnology and management of 
reservoirs in Brazil. Comp. Reserv. Limnol. water Qual. Manag. 25-55. doi:10.1007/97894-017-1096-1_2

U.S. Environmental Protection Agency. 1983. Methods for chemical analysis of water and wastes. Washington, D.C., EPA-600-4-79-020 (NTIS PB84128677).

Vaux, P. D., and C. R. Goldman. 1984. El Cajon project: Ecology, limnology and fisheries program. Available at: hdl.handle.net/10217/89298. Last accessed February 1, 2021.

Verpoorter, C., T. Kutser, D. A. Seekell, and L. J. Tranvik. 2014. A global inventory of lakes based on high-resolution satellite imagery. Geophys. Res. Lett. 41: 6396-6402. doi:10.1002/2014GL060641

Vincent, W. F., W. Wurtsbaugh, C. L. Vincent, and P. J. Richerson. 1984. Seasonal dynamics of nutrient limitation in a tropical high-altitude lake (Lake Titicaca, Peru-Bolivia): Application of physiological bioassays. Limnol. Ocean. 29: 540-552. doi: 10.4319/lo.1984.29.3.0540

Weisman, A., S. Chandra, E. Rejmánková, and E. Carlson. 2018. Effects of nutrient limitations and watershed inputs on community respiration in a deep, tropical lake: Comparison of pelagic and littoral habitats. Water Resour. Res. 54: 5213-5224. doi:10.1029/2017WR021981

Wetzel, R. G. 2001. Limnology, 3rd ed. Elsevier.

Wickham, H. 2016. ggplot2: Elegant Graphics for Data Analysis, Springer-Verlag New York. Wickham, H., M. Averick, J. Bryan, and others. 2019. Welcome to the Tidyverse. J. Open Source Softw. 4: 1686. doi:10.21105/joss.01686

Yu, S., Q. Wu, Q. Li, J. Gao, Q. Lin, J. Ma, Q. Xu, and S. Wu. 2014. Anthropogenic land uses elevate metal levels in stream water in an urbanizing watershed. Sci. Total Environ. 488489: 61-69. doi:10.1016/j.scitotenv.2014.04.061 
Supplementary Table 1. Mean hypolimnetic nutrient values for June 2018 and 2019 with corresponding Secchi depth.

\begin{tabular}{|c|c|c|c|}
\hline & $\mathrm{NH}_{4}^{+}(\mu \mathrm{M})$ & $\mathbf{T P}(\mu \mathrm{M})$ & Secchi depth (m) \\
\hline B & 51.13 & 2.48 & 3.10 \\
\hline $\mathrm{C}$ & 53.89 & 1.40 & 2.84 \\
\hline $\mathbf{E}$ & 55.48 & 2.05 & 3.19 \\
\hline $\mathbf{F}$ & \begin{tabular}{|l|}
46.18 \\
\end{tabular} & 1.40 & 3.20 \\
\hline G & no data & no data & 2.85 \\
\hline $\mathbf{H}$ & 35.15 & 1.95 & 2.78 \\
\hline I & 57.25 & 2.35 & 2.60 \\
\hline $\mathbf{K}$ & 59.37 & 3.23 & 2.59 \\
\hline $\mathbf{M}$ & 66.96 & 1.68 & 2.58 \\
\hline $\mathbf{N}$ & 6.32 & 0.79 & 2.25 \\
\hline 0 & 16.88 & 0.62 & 2.65 \\
\hline $\mathbf{P}$ & 55.48 & 3.42 & 3.20 \\
\hline Q & 67.37 & 3.82 & 2.68 \\
\hline $\mathbf{R}$ & 44.54 & 3.49 & 2.70 \\
\hline
\end{tabular}

